\title{
PENGARUH PENDIDIKAN KESEHATAN TERHADAP PERILAKU PERSONAL HYGIENE SAAT MENSTRUASI PADA SISWI SMP DAN SMA DI YAYASAN PASRAMAN GURUKULA BANGLI
}

\author{
I Dewa Ayu Alit Maharani Laras', Made Rini Damayanti², I Gusti Ayu \\ Pramitaresthi $^{3}$ \\ ${ }^{123}$ Program Studi Sarjana Keperawatan Dan Profesi Ners Fakultas Kedokteran Universitas Udayana \\ Alamat Korespondensi: mhrnlaras@gmail.com
}

\begin{abstract}
ABSTRAK
Perilaku personal hygiene saat menstruasi merupakan salah satu tindakan yang dapat dilakukan untuk mengurangi masalah kesehatan reproduksi. Keefektifan perilaku personal hygiene dapat ditingkatkan dengan memberikan pendidikan kesehatan. Penelitian ini bertujuan untuk mengetahui pengaruh pendidikan kesehatan terhadap perilaku personal hygiene saat menstruasi pada siswi SMP dan SMA di Yayasan Pasraman Gurukula Bangli. Jenis penelitian yang digunakan adalah quasi experimental dengan one group pretest-posttest design. Sampel penelitian berjumlah 43 orang yang dipilih berdasarkan total sampling. Intervensi yang diberikan berupa pendidikan kesehatan dengan metode ceramah dan demonstrasi yang diberikan sebanyak empat kali dengan durasi 60 menit per pertemuan. Data perilaku personal hygiene saat menstruasi dikumpulkan dengan kuisioner pengetahuan, sikap, dan perilaku yang sudah diuji validitas dan reabilitasnya. Data perilaku personal hygiene diuji menggunakan uji t-test berpasangan dan uji Wilcoxon. Hasilnya didapatkan $\mathrm{p}=0,001 ; \alpha<0,05$ yang artinya ada pengaruh pendidikan kesehatan terhadap pengetahuan, sikap, dan tindakan personal hygiene pada siswi SMP dan SMA di Yayasan Pasraman Gurukula Bangli. Saran untuk siswa mampu untuk menerapkan tindakan personal hygiene sesuai dengan materi pendidikan kesehatan yang telah diberikan dengan memperhatikan sarana dan prasarananya dan peneliti selanjutnya diharapkan dapat menggunakan lembar observasi untuk melihat tindakan siswi dalam melakukan personal hygiene saat menstruasi.
\end{abstract}

Kata Kunci: Menstruasi, pendidikan kesehatan, personal hygiene

\begin{abstract}
Personal hygiene behavior during menstruation is one of actions that can be done to reduce reproductive health problems. The effectiveness of personal hygiene behavior can be improved by giving health education. This study aimed to determine the effect of health education on personal hygiene behavior during menstruation among middle and high school students at Pasraman Gurukula Bangli Foundation. This study was quasi-experimental with one group pretest-posttest design. Sample of this research was 43 respondents that selected by total sampling technique. Health education as an intervention was given by lecture and demonstration methods, four times with a duration of 60 minutes on each meeting. Data on personal hygiene behavior during menstruation were collected by questionnaire of knowledge, attitudes, and behaviors that had been tested for validity and reliability. Personal hygiene behaviors data were analyzed using paired t-test and Wilcoxon test. The result shows that $\mathrm{p}$ value $=0.001 ; \alpha<0.05$, so it means that there is an effect of health education on knowledge, attitudes, and personal hygiene behaviors among middle and high school students at Bangli Pasraman Gurukula Foundation. It is suggested for students to apply personal hygiene well in accordance with the health education material that has been given with existing facilities and infrastructure and further researchers are expected to be able to use observation form to observe students' behaviors in carrying out personal hygiene during menstruation.
\end{abstract}

Keywords: Health education, menstruation, personal hygiene 


\section{PENDAHULUAN}

Masa remaja merupakan masa peralihan dari anak-anak menuju dewasa yang disertai pertumbuhan dan perkembangan fisik, psikologis, dan intelektual (Herlina, 2013). Tahap remaja dimulai dari usia 10-19 tahun yang jumlahnya sekitar $42 \%$ dari populasi di dunia pada tahun 2016 (WHO, 2018). Di Indonesia jumlah remaja berusia 1024 tahun mencapai 66,9 juta pada tahun 2017 (Bappenas, 2018). Pada remaja terjadipertumbuhan dan perkembangan fisik yang berhubungan dengan pubertas.

Pubertas adalah masa pematangan seksual yang dialami oleh perempuan di usia 10-14 tahun dan laki-laki pada usia 12-16 tahun (Stöppler, 2018). Pubertas pada perempuan ditandai dengan menstruasi yaitu pengeluaran darah secara teratur setiap bulan dari rahim (Sinaga dkk, 2017). Remaja perempuan dapat mengalami masalah saat menstruasi baik fisiologis (dalam batas normal) atau patologis (perlu diwaspadai). Implikasi dari permasalahan terkait menstruasi tersebut dapat mempengaruhi kesehatan organ reproduksi.

Kesehatan reproduksi pada wanita dapat dijaga dengan melakukan personal hygiene yaitu suatu tindakan untuk memelihara kebersihan dan kesehatan seseorang. Kebersihan pada daerah kewanitaan saat menstruasi sangat penting untuk dijaga karena kuman mudah masuk dan dapat menyebabkan penyakit pada organ reproduksi (Kusmiran, 2012).

Penelitian yang dilakukan oleh Bansal (2017) menyatakan bahwa sebanyak $77,5 \%$ remaja putri dalam penelitian tersebut memiliki personal hygiene yang tidak baik saat menstruasi. Keefektifan perilaku personal hygiene dapat ditingkatkan dengan memberikan pendidikan kesehatan sebagai salah satu cara untuk menambah pengetahuan siswi sehingga terjadi perubahan positif pada perilaku kesehatan (Prasetiya,
2015; Coalition of National Health Education Organizations, 2015). Penelitian Sari (2013) menyatakan bahwa sekolah dapat menjadi salah satu tempat yang ideal untuk memberikan pendidikan kesehatan karena adanya interaksi antara siswa dan guru yang diharapkan mampu meningkatan perilaku kesehatan siswa.

Sekolah merupakan salah satu tempat yang dapat digunakan untuk meningkatkan pengetahuan termasuk pengetahuan kesehatan agar dapat membantu siswa tetap sehat (Centers for Disease Control and Prevention, 2016). Boarding school atau sekolah asrama merupakan sistem pendidikan berbasis pesantren dan madrasah yang bertujuan untuk melaksanakan pendidikan komprehensif baik ilmu sains, teknologi, dan spiritual. Perkembangan modernitas yang menyebabkan orang tua tidak mampu melakukan pengawasan karena harus bekerja membuat boarding school menjadi pilihan terbaik untuk menitipkan anak (Kaifa, 2013).

Penelitian Dewi (2012) yang membandingkan pengetahuan siswi di SMA dengan siswi boarding school terkait kesehatan reproduksi mendapatkan hasil bahwa pengetahuan siswi di SMA lebih tinggi dibandingkan dengan pengetahuan siswi di boarding school. Susanto (2014) juga mendapatkan bahwa personal hygiene seperti kebersihan kulit, rambut, dan tangan pada siswa di pesantren Al-Athiyah Lembah Selawah Aceh Besar dikatagorikan kurang baik.

Yayasan Pasraman Gurukula Bangli merupakan salah satu sekolah yang menerapkan sistem boarding school. Hasil studi pendahuluan yang dilakukan, didapatkan hasil bahwa penerapan personal hygiene saat menstruasi masih kurang. Pembalut idealnya diganti setiap 3-4 jam sekali untuk menghindari terjadinya infeksi, iritasi, dan lecet (UNICEF, 2016).

Hasil studi literatur yang dilakukan peneliti mendapatkan bahwa 
penelitian terkait pengaruh pendidikan kesehatan terhadap perilaku personal hygiene saat menstruasi lebih banyak dilakukan pada sekolah umum dan masih jarang dilakukan di sekolah berasrama. Penelitian ini menggunakan metode gabungan antara ceramah dan simulasi sehingga sesuai dengan sasaran yang memiliki perbedaan tingkat pendidikan. Penelitian oleh Bany, dkk (2014) menunjukkan bahwa terdapat peningkatan skor pengetahuan yang bermakna pada kedua metode yaitu ceramah dan demonstrasi. Berdasarkan hal tersebut, peneliti tertarik untuk mengetahui pengaruh pendidikan kesehatan terhadap perilaku personal hygiene saat menstruasi pada siswi SMP dan SMA di Yayasan Pasraman Gurukula Bangli.

\section{METODE PENELITIAN}

Jenis penelitian ini yaitu penelitian quasi experimental dengan rancangan one-group pretest-posttest design. Penelitian dilakukan di Yayasan Pasraman Gurukula, Kecamatan Kubu, Kabupaten Bangli. Penelitian dilakukan dari tanggal 17 Mei 2019 hingga 1 Juni 2019.

Populasi dalam penelitian ini adalah semua siswi SMP dan SMA yang bersekolah di Yayasan Pasraman Gurukula Bangli. Teknik pengambilan sampel yang digunakan adalah total sampling. Sampel penelitian ini berjumlah 43 orang. Kriteria inklusi penelitian ini yaitu telah mendapat ijin dari wali/kepala sekolah dan telah mengalami menarche atau menstruasi. Kriteria drop out dalam penelitian ini yaitu tidak mengikuti kegiatan dari awal sampai akhir penelitian.

Instrumen penelitian ini yaitu kuisioner perilaku personal hygiene saat menstruasi dari penelitian Zahara (2014) yang telah dimodifikasi. Uji validitas dan reliablitas dilakukan kembali oleh peneliti di SMA N Bali
Mandara merupakan sekolah dengan sistem boarding school di Bali memiliki karakteristik yang serupa dengan siswi di Yayasan Pasraman Gurukula Bangli. Hasil uji validitas kuesioner menunjukkan bahwa penyataan pengetahuan, sikap, dan tindakan memiliki nilai $\mathrm{r}$ hitung $>0,361$ dan nilai $\mathrm{p} \leq 0,05$ sehingga dinyatakan valid. Hasil uji reliabilitas menunjukkan bahwa Cronbach alpa pernyataan pengetahuan yaitu 0,78 , Cronbach alpa pernyataan sikap yaitu 0,716, dan Cronbach alpa pernyataan tindakan yaitu 0,835 , sehingga dinyatakan reliabel.

Penelitian ini telah mendapat ijin dan surat keterangan ethical clearence dari Komisi Etika Penelitian FK Unud/RSUP Sanglah. Pengumpulan data dilakukan dengan memberikan kuesioner untuk pretest pada responden selama kurang lebih 25 menit. Pada minggu berikutnya siswi diberikan pendidikan kesehatan. Pertemuan pertama siswi diberikan materi tentang remaja dan perkembangannya dengan media power point dengan metode ceramah, pertemuan kedua diberikan materi tentang menstruasi dengan media power point dan video dan metode yang digunakan adalah ceramah, pertemuan ketiga diberikan materi tentang personal hygiene dengan media power point dan video dengan metode ceramah, dan pada pertemuan keempat diberikan materi tentang personal hygiene saat menstruasi dengan media power point, leaflet, dan video dengan metode ceramah dan permainan simulasi. Pada setiap pertemuan, materi diberikan selama 60 menit. Pada minggu terakhir, responden diminta untuk mengisi kuesioner posttest selama kurang lebih 25 menit. Data yang terkumpul dilakukan tabulasi dan analisis data.

Analisis data yang digunakan pada penelitian ini yaitu analisis univariat untuk mengetahui distribusi frekuensi karakteristik responden. Analisis bivariat juga digunakan untuk 
membandingkan perbedaan perilaku personal hygiene sebelum dan setelah Wilcoxon dengan derajat kemaknaan $95 \%$ atau nilai $\mathrm{p} \leq 0,05$ sebagai acuan untuk pengambilan keputusan.

\section{HASIL PENELITIAN}

Hasil penelitian pada karakteristik responden menunjukkan bahwa sebagian besar responden berusia 16 tahun yaitu 15 orang $(34,9 \%)$, berada di kelas X SMA yaitu sebanyak 20 orang $(46,5 \%)$ dan seluruh responden beragama Hindu. Hasil penelitan terkait distribusi pengetahuan, sikap, dan tindakan pretest diberikan pendidikan kesehatan menggunakan uji $\mathrm{t}$ berpasangan dan uji dan posttest siswi tentang personal hygiene saat menstruasi ditunjukkan pada tabel 1 yaitu rata-rata pengetahuan responden meningkat setelah diberikan pendidikan kesehatan dari 20,30 $( \pm 2,455)$ menjadi 28,02 $( \pm 1,611)$. Rata-rata nilai sikap meningkat setelah diberikan pendidikan kesehatan dari 23,72 $( \pm 2,142)$ menjadi 31,81 $( \pm 2,881)$. Rata-rata nilai tindakan meningkat setelah diberikan pendidikan kesehatan dari 6,14 $( \pm 0,743)$ menjadi 8,88 $( \pm 0,956)$.

Tabel 1 Hasil Distribusi Pengetahuan, Sikap, dan Tindakan Pretest dan Posttest Siswi tentang Personal Hygiene saat Menstruasi di Yayasan Pasraman Gurukula Bangli

\begin{tabular}{lcccc}
\hline \multicolumn{1}{c}{ Variabel } & n & Median & Mean \pm SD & CI 95\% \\
\hline Pengetahuan pretest & 43 & 20 & $20,30 \pm 2,455$ & $19,55-21,06$ \\
\hline Pengetahuan posttest & 43 & 28 & $28,02 \pm 1,611$ & $27,53-28,52$ \\
\hline Sikap pretest & 43 & 24 & $23,72 \pm 2,142$ & $23,06-24,38$ \\
\hline Sikap posttest & 43 & 32 & $31,81 \pm 2,881$ & $30,93-32,70$ \\
\hline Tindakan pretest & 43 & 6 & $6,14 \pm 0,743$ & $5,91-6,37$ \\
\hline Tindakan posttest & 43 & 9 & $8,88 \pm 0,956$ & $8,59-9,18$ \\
\hline
\end{tabular}

Tabel 2 Hasil Distribusi Pengetahuan, Sikap, dan Tindakan Pretest dan Posttest Siswi tentang Personal Hygiene saat Menstruasi Berdasarkan Usia dan Kelas

\begin{tabular}{|c|c|c|c|c|}
\hline Var & Usia (th) & Mean \pm SD & Kelas & Mean \pm SD \\
\hline \multirow[t]{5}{*}{ Pengetahuan pretest } & 13 & $19,29 \pm 1,496$ & VII & $19,67 \pm 0,577$ \\
\hline & 14 & $18,75 \pm 3,775$ & VIII & $19,40 \pm 1,140$ \\
\hline & 15 & $20,57 \pm 0,787$ & IX & $19,25 \pm 3,370$ \\
\hline & 16 & $19,53 \pm 2,326$ & $\mathrm{X}$ & $20,45 \pm 2.502$ \\
\hline & 17 & $22,60 \pm 2,066$ & XI & $22,00 \pm 1,528$ \\
\hline \multirow[t]{5}{*}{ Pengetahuan posttest } & 13 & $28,29 \pm 1,496$ & VII & $28,33 \pm 1,155$ \\
\hline & 14 & $27,75 \pm 1,708$ & VIII & $28,40 \pm 1,817$ \\
\hline & 15 & $28,14 \pm 1,345$ & IX & $27,88 \pm 1,553$ \\
\hline & 16 & $28,47 \pm 1,302$ & $\mathrm{X}$ & $27,95 \pm 1,820$ \\
\hline & 17 & $27,20 \pm 2,150$ & $\mathrm{XI}$ & $28,00 \pm 1,414$ \\
\hline \multirow[t]{5}{*}{ Sikap pretest } & 13 & $23,00 \pm 2,380$ & VII & $22,00 \pm 1,732$ \\
\hline & 14 & $22,75 \pm 3,594$ & VIII & $23,20 \pm 2,864$ \\
\hline & 15 & $23,86 \pm 1,464$ & IX & $23,00 \pm 2,449$ \\
\hline & 16 & $23,00 \pm 1,134$ & $\mathrm{X}$ & $23,50 \pm 1,192$ \\
\hline & 17 & $25,60 \pm 2,066$ & XI & $26,29 \pm 1,976$ \\
\hline \multirow[t]{5}{*}{ Sikap posttest } & 13 & $31,86 \pm 2,268$ & VII & $32,33 \pm 2,082$ \\
\hline & 14 & $32,50 \pm 2,887$ & VIII & $32,20 \pm 2,280$ \\
\hline & 15 & $31,14 \pm 2,610$ & IX & $32,75 \pm 2,866$ \\
\hline & 16 & $32,00 \pm 3,140$ & $\mathrm{X}$ & $31,10 \pm 3,177$ \\
\hline & 17 & $31,70 \pm 3,466$ & XI & $32,29 \pm 2,870$ \\
\hline \multirow[t]{2}{*}{ Tindakan pretest } & 13 & $6,57 \pm 0,976$ & VII & $6,33 \pm 0,577$ \\
\hline & 14 & $5,75 \pm 0,500$ & VIII & $6,60 \pm 1,140$ \\
\hline
\end{tabular}




\begin{tabular}{lcccc}
\cline { 2 - 5 } & 15 & $6,29 \pm 0,488$ & IX & $6,00 \pm 0,535$ \\
\cline { 2 - 5 } Tindakan posttest & 16 & $6,13 \pm 0,640$ & X & $6,05 \pm 0,759$ \\
& 17 & $5,90 \pm 0,876$ & XI & $6,14 \pm 0,690$ \\
\cline { 2 - 5 } & 13 & $8,57 \pm 0,535$ & VII & $9,33 \pm 0,577$ \\
\hline 14 & $8,75 \pm 0,957$ & VIII & $8,60 \pm 0,548$ \\
\hline 15 & $9,14 \pm 0,690$ & IX & $8,88 \pm 0,835$ \\
\hline 16 & $9,00 \pm 0,845$ & X & $8,70 \pm 1,129$ \\
\hline
\end{tabular}

Tabel 3 Hasil Uji Statistik Data Pretest dan Posttest Pengetahuan Personal Hygiene saat Menstruasi

\begin{tabular}{ccccc}
\hline Pengetahuan & Rata-rata & Selisih & CI 95\% & P \\
\hline Pretest $(\mathrm{n}=43)$ & 20,30 & $-7,72$ & $-6,77(-8,66)$ & 0,001 \\
Posttest $(\mathrm{n}=43)$ & 28,02 & & & \\
\hline \multicolumn{4}{l}{ Keterangan: Uji t-test berpasangan; Selisih antara sesudah dan sebelum }
\end{tabular}

Tabel 4 Hasil Uji Statistik Data Pretest dan Posttest Sikap Personal Hygiene saat Menstruasi Keterangan: Uji $t$-test berpasangan; Selisih antara sesudah dan sebelum

\begin{tabular}{ccccc}
\hline Sikap & Rata-rata & Selisih & CI 95\% & p \\
\hline Pretest $(\mathrm{n}=43)$ & 23,72 & $-8,09$ & $-7,01(-9,16)$ & 0,001 \\
Posttest $(\mathrm{n}=43)$ & 31,81 & & & \\
\hline
\end{tabular}

Keterangan: Uji $t$-test berpasangan; Selisih antara sesudah dan sebelum

Tabel 5 Hasil Uji Statistik Data Pretest dan Posttest Tindakan Personal Hygiene saat Menstruasi

\begin{tabular}{ccc}
\hline Tindakan & Median & p \\
\hline Pretest $(\mathrm{n}=43)$ & 6 & 0,001 \\
Posttest $(\mathrm{n}=43)$ & 9 & \\
\hline
\end{tabular}

Keterangan: Uji Wilcoxon, 42 subjek tindakan meningkat, dan 1 tetap

Hasil penelitian terkait pengetahuan pretest posttest ditampilkan pada tabel 2 yaitu rerata pengetahuan pretest siswi berdasarkan kelompok usia paling rendah pada usia 14 tahun yaitu 18,75 dan paling tinggi pada usia 17 tahun yaitu 22,60. Sedangkan rerata pengetahuan posttest siswi paling rendah pada usia 17 tahun yaitu 27,20 dan paling tinggi pada usia 16 tahun yaitu 28,47.

Berdasarkan kelas rerata pengetahuan pretest siswi paling rendah pada kelas IX SMP yaitu 19,25 dan paling tinggi pada kelas XI SMA yaitu 22,00. Sedangkan rerata pengetahuan posttest siswi paling rendah pada kelas IX SMP yaitu 27,88 dan paling tinggi pada kelas VIII SMP yaitu 28,40.

Tabel 2 menunjukkan bahwa rerata sikap pretest siswi paling rendah pada usia 14 tahun yaitu 22,75 dan paling tinggi pada usia 17 tahun yaitu 25,60. Sedangkan rerata sikap posttest siswi paling rendah pada usia 15 tahun yaitu 31,14 dan paling tinggi pada usia 14 tahun yaitu 32,50 .

Berdasarkan kelas rerata sikap pretest siswi paling rendah kelas VIII SMP yaitu 22,00 dan paling tinggi pada kelas X SMA yaitu 23,50. Sedangkan rerata pengetahuan posttest siswi paling rendah pada kelas X SMA yaitu 31,10 dan paling tinggi pada kelas IX SMP yaitu 32,75 .

Tabel 2 menunjukkan rerata tindakan pretest siswi paling rendah pada usia 14 tahun yaitu 5,75 dan paling tinggi pada usia 13 tahun yaitu 6,57. Sedangkan rerata tindakan posttest siswi paling rendah pada pada usia 13 tahun yaitu 8,57 
dan paling tinggi pada usia 15 tahun yaitu 9,14 .

Berdasarkan kelas rerata tindakan pretest siswi paling rendah pada kelas IX SMP yaitu 6,00 dan paling tinggi pada kelas VIII SMP yaitu 6,60. Sedangkan rerata tindakan posttest siswi paling rendah pada kelas VIII SMP yaitu 8,60 dan paling tinggi pada kelas XI SMA yaitu 9,43 .

Uji t-test berpasangan dipilih karena selisih data pretest dan posttest pengetahuan terdistribusi normal $(\mathrm{p}=0,256, \mathrm{p}>0,05)$. Tabel 3 menunjukkan hasil uji t-test berpasangan terdapat perbedaan rata-rata yang signifikan antara data pretest pengetahuan dengan posttest pengetahuan pada responden $\mathrm{p}=0,001$ $(\mathrm{p}<0,05)$.

Hasil uji $t$-test berpasangan terkait pretest dan posttest sikap ditampilkan pada tabel 4 yaitu menunjukkan secara statistik terdapat perbedaan rata-rata yang signifikan antara data pretest sikap dengan posttest sikap pada responden $\mathrm{p}=0,001 \quad(\mathrm{p}<0,05)$. Uji t-test berpasangan dipilih karena selisih data pretest dan posttest sikap terdistribusi normal $(\mathrm{p}=0,312, \mathrm{p}>0,05)$.

Uji wilcoxon dipilih karena selisih data pretest dan posttest tindakan tidak terdistribusi normal $(\mathrm{p}=0,005, \mathrm{p}<0,05)$. Tabel 5 hasil uji wilcoxon menunjukkan bahwa secara statistik terdapat perbedaan rata-rata yang signifikan antara data pretest tindakan dengan posttest tindakan pada responden $\mathrm{p}=0,001(\mathrm{p}<0,05)$.

\section{PEMBAHASAN}

Rata-rata pengetahuan responden mengalami peningkatan yaitu sebelum diberikan pendidikan kesehatan paling tinggi pada kelompok usia 17 tahun yaitu 22,60 dan setelah diberikan pendidikan kesehatan paling tinggi berada pada kelompok usia 16 tahun yaitu 28,47. Umairoh (2014) menyatakan bahwa usia dapat mempengaruhi daya tangkap dan pola pikir, sehingga usia yang semakin bertambah, daya tangkap dan pola pikir juga berkembang.

Rata-rata sikap pada responden mengalami peningkatan yang signifikan yaitu sebelum diberikan pendidikan kesehatan paling tinggi pada kelompok usia 17 tahun yaitu 25,60 dan setelah diberikan pendidikan kesehatan paling tinggi berada pada kelompok usia 14 tahun yaitu 32,50. Hasil nilai sikap tentang personal hygiene sebelum diberikan pendidikan kesehatan menunjukkan hasil dalam katagori baik. Anwar dalam Umairoh (2014) menyatakan bahwa faktor yang mempengaruhi sikap yaitu pengalaman, pengaruh orang lain, media massa, dan lenbaga pendidikan. Hasil pengetahuan dalam katagori baik sebelum diberikan intervensi karena informasi yang dimiliki responden sudah cukup baik yang mungkin diperoleh dari pelajaran IPA tentang reproduksi.

Rata-rata tindakan pada responden mengalami peningkatan yang signifikan yaitu sebelum diberikan pendidikan kesehatan paling tinggi pada kelompok usia 13 tahun yaitu 6,57 dan setelah diberikan pendidikan kesehatan paling tinggi berada pada kelompok usia 15 tahun yaitu 9,14. Supatmi dan Adyani (2016) menyatakan bahwa body image pada usia remaja sangat penting sehingga responden memiliki upaya atau tindakan untuk dapat mencapai ideal diri yang diinginkannya salah satunya dengan meningkatkan personal hygienenya.

Rata-rata pengetahuan pada responden dilihat dari kelas, sebelum diberikan pendidikan kesehatan paling tinggi pada kelas XI SMA yaitu 22,00 dan setelah diberikan pendidikan kesehatan rata-rata pengetahuan paling tinggi berada pada kelas VIII SMP yaitu 28,40. Pengetahuan yang baik sebelum pendidikan kesehatan pada kelas XI SMA menurut Ross (1999) dalam Pradono dan Sulistyowati (2014) karena terdapat pengaruh positif dari lamanya pendidikan 
selanjutnya untuk melakukan penelitian tentang tindakan personal hygiene saat menstruasi disertai dengan melakukan observasi. Institusi sekolah dapat bekerjasama dengan petugas kesehatan diharapkan agar tetap memberikan pendidikan kesehatan tentang cara menjaga personal hygiene terutama personal hygiene saat menstruasi dan juga menyediakan sarana dan prasarana yang memadai seperti air, tisu, dan pembalut untuk mendukung siswi melaksanakan personal hygiene dengan baik.

\section{DAFTAR PUSTAKA}

Astuti, R \& Utami, I. (2017). Hubungan pengetahuan tentang personal hygiene dengan perilaku personal hygiene saat menstruasi pada remaja putri kelas XI di SMA Negeri 1 Pajangan Bantul. Skripsi Thesis, Universitas Aisyiyah Yogyakarta

Badan Perencanaan Pembangunan Nasional (Bappenas). (2018). Jumlah penduduk Indonesia mencapai 265 juta jiwa. Retrieved from: https://databoks.katadata.co.id/ (diakses pada tanggal 26 Februari 2019)

Bansal, B. (2017). Importance of maintaining good hygiene during periods. Retrieved from: https://www.practo.com/ (diakses pada 17 Februari 2019)

Bany, Z. U., Sunnati, \& Darman, W. (2014). Perbandingan efektifitas penyuluhan metode ceramah dan demonstrasi terhadap pengetahuan kesehatan gigi dan mulut siswa. Journal Cakradonya Dent, 6(1)

Bontong, N. E., Engkeng, S., \& Asrifuddin, A. (2017). Perbedaan sebelum dan sesudah penyuluhan kesehatan terhadap perilaku personal hygiene saat menstruasi pada pelajar putri di SMP Negeri 14 Kota Manado. Jurnal Kesehatan Masyarakat, 6(3)

Centers for Disease Control and Prevention (CDC). (2016). Healthy schools, successful students. Retrieved from: https://www.cdc.gov/ (Diakses pada tanggal 10 Desember 2018)

Coalition of National Health Education Organizations. (2015). What is health education? Retrieved from: http://www.cnheo.org/ (diakses pada tanggal 26 Februari 2019)

Dewi, H. M. (2012). Perbedaan tingkat pengetahuan tentang kesehatan reproduksi pada siswa boarding school pondok pesantren al-salaam dan siswa SMA Negeri di wilayah kecamatan Surakarta. Skripsi, Universitas Muhammadiyah Surakarta

Harahap, R. A. (2016). Pengaruh Faktor Predisposing, Enabling dan Reinforcing Terhadap Pemberian Imunisasi Hepatitis B pada Bayi di Puskesmas Bagan Batu Kecamatan Bagan Sinembah Kabupaten Rokan Hilir. Jurnal JUMANTIK, 1(1)

Herlina. (2013). Mengatasi masalah anak dan remaja melalui buku. Bandung: Pustaka Cendekia Utama.

Kaifa, K. (2013). Boarding School. Retrieved from: eprints.ums.ac.id/ (diakses pada tanggal 4 Oktober 2018)

Kusmiran, E. (2012). Kesehatan reproduksi remaja dan wanita. Jakarta: Salemba

Notoatmodjo, S. (2012). Promosi kesehatan dan perilaku kesehatan. Jakarta: Rineka Cipta

Pradono, J. \& Sulistyowati, N. (2014). Hubungan antara Tingkat Pendidikan, Pengetahuan tentang Kesehatan Lingkungan, Perilaku Hidup Sehat dengan Status Kesehatan. Buletin Penelitian Sistem Kesehatan,17(1)

Prasetiya, C. H. (2015). Efektifitas Pendidikan Kesehatan terhadap Peningkatan Pengetahuan Keluarga tentang Hipertensi. Jurnal Kedokteran dan Kesehatan, 15(1)

Sari, T. P. (2013). Pendidikan Kesehatan Sekolah sebagai Proses Perubahan Perilaku Siswa. JPJI, 9(2)

Sinaga, E., Saribanon, N., Sa' adah, SN., Salamah, U., Murti, YA., Trisnamiati, A. \& Lorita, S. (2017). Manajemen kesehatan menstruasi. Jakarta: Universitas Nasional

Stöppler, M. C. (2018). Puberty. Retrieved from: https://www.medicinenet.com/ (diakses pada tanggal 26 Februari 2019)

Supatmi \& Adyani, A. (2016). Tindakan Personal Hygiene (Vulva Hygiene) Saat Menstruasi Pada Siswi Smp Muhammadiyah X Surabaya. Jurnal publikasi

Susanto, E. (2014). Gambaran personal hygiene pada remaja di pesantren al-athiyah lembah selawah aceh besar tahun 2014. Tesis, Universitas Syiah Kuala

Syaputri, P. (2014). Hubungan Tingkat Pendidikan, Status Ekonomi, dan Lingkungan dengan Perilaku Seks Remaja (14-17 tahun) di Gampong Kuta Padang Kecamatan Johan Pahlawan Kabupaten Aceh Barat. Skripsi, Universitas Teuku Umar

Umairoh, C. (2014). Analisis Faktor yang Mempengaruhi Perilaku Perineal Hygiene pada Remaja Putri Berbasis Precede Proceed Model di SMPN 45 Surabaya. Jurnal Publikasi 
UNICEF. (2016). Panduan khusus anak perempuan untuk sekolah dasar dan madrasah ibtidaiyah. Bandung

World Health Organization (WHO). (2018). Coming of age- adolescent health. Retrieved from: http://www.who.int/ (diakses pada tanggal 4 Oktober 2018)
Zahara, C. R. (2014). Hubungan penyuluhan tentang personal hygiene dengan perilaku remaja putri pada saat menstruasi di SMU Cut Nyak Dhien Langsa tahun 2014. Tesis, Universitas Sumatera Utara 